\title{
PENGARUH PROFITABILITAS, STRUKTUR AKTIVA, UKURAN PERUSAHAAN, LIKUIDITAS, DAN PERTUMBUHAN PENJUALAN TERHADAP STRUKTUR MODAL PERUSAHAAN SEKTOR MANUFAKTUR YANG TERDAFTAR DI BURSA EFEK INDONESIA SELAMA PERIODE 2014-2018
}

\author{
Claudia Gita Hapsari \\ Program Studi Magister Manajemen Universitas Tarumanagara \\ drabble_lyre@hotmail.com \\ Indra Widjaja \\ Program Studi Magister Manajemen Universitas Tarumanagara
}

Masuk : 20-05-2020, revisi : 23-06-2020 diterima untuk diterbitkan : 24-06-2020

\begin{abstract}
The purpose of this study is to examine the effect of profitability, asset structure, company size, liquidity, and sales growth on the capital structure of the companies listed in Bursa Efek Indonesia from 2014 to 2018. This research studies 92 samples from 178 manufacturing companies. The data is processed using Eviews 9.0. The result shows that profitability, asset structure, company size, and sales growth have significant effect on the capital structure. This research also finds that profitability, asset structure, company size, liquidity, and sales growth have a simultaneous and significant effect on the capital structure of manufacturing companies in Indonesia.
\end{abstract}

Abstrak : Penelitian ini bertujuan untuk menguji pengaruh profitabilitas, struktur aktiva, ukuran perusahaan, likuiditas, dan pertumbuhan penjualan terhadap struktur modal perusahaan manufaktur yang terdaftar sebagai emiten Bursa Efek Indonesia selama periode 2014-2018. Penelitian ini meneliti sebanyak 92 sampel perusahaan manufaktur dari total populasi sebanyak 178 perusahaan. Teknik pengolahan data yang digunakan dalam penelitian ini adalah analisis regresi berganda, diolah menggunakan Eviews 9.0. Hasil penelitian ini menunjukkan bahwa struktur aktiva, ukuran perusahaan, likuiditas, dan pertumbuhan penjualan memiliki pengaruh signifikan terhadap struktur modal. Penelitian ini juga menemukan bahwa profitabilitas, struktur aktiva, ukuran perusahaan, likuiditas, dan pertumbuhan penjualan memiliki pengaruh simultan dan signifikan terhadap struktur modal perusahaan-perusahaan manufaktur di Indonesia.

Keywords : Capital Structure, Profitability, Asset Structure, Company Size, Liquidity, Sales Growth

\section{PENDAHULUAN}

Tujuan utama manajemen keuangan adalah memaksimalkan nilai perusahaan yang tercermin oleh harga saham di pasar modal untuk meningkatkan kemakmuran pemegang saham. (Keown, 2010) Dalam rangka mencapai tujuan tersebut, seorang manajer keuangan menghadapi kewajiban untuk melakukan pengambilan keputusan investasi, keputusan pendanaan, dan keputusan dividen. Keputusan yang paling penting dalam manajemen keuangan untuk meningkatkan nilai perusahaan adalah keputusan pendanaan (Copeland dan Weston 1995). Keputusan manajemen keuangan dalam hal pendanaan berkaitan dengan komposisi utang, saham preferen, dan saham biasa yang mendanai kegiatan perusahaan dalam bentuk struktur modal. (Gitman, 2000). Tugas manajer keuangan dalam mengambil keputusan pendanaan adalah menyusun komposisi hutang jangka panjang dan ekuitas dengan 
meminimalkan biaya modal yang harus ditanggung suatu perusahaan (Prabansari dan Kusuma, 2005).

Dalam menyusun komposisi struktur modal, manajer keuangan harus mempertimbangkan kondisi internal dan eksternal perusahaan yang dapat mempengaruhi tinggi rendahnya cost of capital (biaya modal) dari pemilihan sumber dana tersebut. Berdasarkan pendapat Brigham (2011), komposisi struktur modal dipengaruhi oleh beberapa faktor, baik yang dapat maupun tidak dapat diukur. Faktor-faktor yang mempengaruhi penyusunan struktur modal adalah pertumbuhan penjualan, stabilitas penjualan, struktur aktiva, profitabilitas, pajak, risiko bisnis, sikap manajemen, kontrol manajemen, sikap kreditur, kondisi pasar, penilaian rating agency, (perusahaan penilai kredibilitas), keadaan internal perusahaan, dan fleksiblitas keuangan.

Salah satu sektor yang memberikan kontribusi yang sangat besar bagi perekonomian Indonesia adalah sektor manufaktur. Perusahaan-perusahaan di sektor manufaktur mengolah bahan baku menjadi suatu produk baik secara fisik maupun kimia. Industri ini sangat penting bagi Indonesia karena menyerap banyak tenaga kerja sehingga dapat mengurangi pengangguran dan menjadi mata pencaharian bagi rakyat Indonesia. Berdasarkan data BPS, sektor manufaktur telah memberikan kontribusi terhadap PDB sebesar 20,38\% secara rata-rata selama tahun 2015-2018.

Penelitian ini menggunakan perusahaan-perusahaan sektor manufaktur karena mengingat kontribusinya yang besar bagi PDB Indonesia dan penting bagi penyediaan lapangan kerja bagi masyarakat Indonesia. Sektor manufaktur juga memiliki tingkat sustainability yang tinggi mengingat jumlah penduduk Indonesia yang terus bertambah dari tahun ke tahun yang dapat menunjang tingkat konsumsi produk barang dan jasa. Selain itu, kegiatan manufaktur yang selalu membutuhkan perkembangan teknologi juga menyebabkan perusahaan manufaktur menjadi bersifat padat modal, sehingga sangat sesuai dengan penelitian yang membahas mengenai struktur modal.

\section{TUJUAN PENELITIAN}

Berdasarkan fenomena yang telah dijelaskan di atas, tujuan penelitian ini adalah:

1. Mengetahui pengaruh profitabilitas terhadap struktur modal emiten perusahaan sektor manufaktur yang terdaftar di Bursa Efek Indonesia selama periode 2014-2018.

2. Mengetahui pengaruh struktur aktiva terhadap struktur modal emiten perusahaan sektor manufaktur yang terdaftar di Bursa Efek Indonesia selama periode 2014-2018.

3. Mengetahui pengaruh ukuran perusahaan terhadap struktur modal emiten perusahaan sektor manufaktur yang terdaftar di Bursa Efek Indonesia selama periode 2014-2018.

4. Mengetahui pengaruh likuiditas terhadap struktur modal emiten perusahaan sektor manufaktur yang terdaftar di Bursa Efek Indonesia selama periode 2014-2018.

5. Mengetahui pengaruh pertumbuhan penjualan terhadap struktur modal emiten perusahaan sektor manufaktur yang terdaftar di Bursa Efek Indonesia selama periode 2014-2018.

6. Mengetahui pengaruh profitabilitas, struktur aktiva, ukuran perusahaan, likuiditas, dan pertumbuhan penjualan secara simultan terhadap struktur modal emiten perusahaan sektor manufaktur yang terdaftar di Bursa Efek Indonesia selama periode 2014-2018.

\section{TINJAUAN PUSTAKA}

Struktur modal merupakan komponen yang sangat penting dalam penentuan kebijakan pendanaan perusahaan. Menurut Sartono (2010), struktur modal adalah struktur yang menunjukkan perbandingan hutang jangka panjang, saham preferen, dan saham biasa yang terletak di bagian kanan neraca suatu perusahaan. Fahmi (2011) menjelaskan bahwa struktur modal menunjukan perimbangan keuangan perusahaan antara modal yang berasal dari longterm liabilities (hutang jangka panjang) dan shareholder's equity (modal sendiri) yang 
digunakan sebagai sumber pendanaan untuk pembelanjaan kegiatan operasional perusahaan. Pendanaan struktur modal dapat bersumber dari pembiayaan internal maupun pembiyaan eksternal. Setiap pilihan keputusan pendanaan akan menimbulkan biaya modal yang akan meningkatkan tingkat rate of return yang diinginkan oleh pemegang saham.

Brigham dan Houston (2011) menyebutkan bahwa perusahaan yang memiliki tingkat pengembalian yang lebih tinggi cenderung untuk memiliki tingkat hutang yang relative lebih kecil. Hal ini sesuai dengan Pecking Order Theory yang menyebutkan bahwa perusahaan memiliki preferensi terhadap pendanaan internal dibandingkan pendanaan eksternal. Pecking Order Theory menjelaskan alasan perusahaan yang memiliki tingkat profitabilitas yang tinggi cenderung memiliki tingkat hutang yang rendah. Perusahaan yang memiliki tingkat keuntungan yang tinggi akan memiliki lebih banyak dana internal yang digunakan untuk kegiatan investasi, sehingga tidak akan menggunakan hutang yang merupakan pendanaan eksternal.

Trade Off Theory merupakan teori struktur modal yang pertama kali diperkenalkan oleh Modigliani dan Miller pada tahun 1963. Menurut Brigham dan Houston (2011), Trade Off Theory adalah teori yang berkaitan dengan penyeimbangan antara risiko dan tingkat pengembalian yang diambil dengan menyusun struktur modal. Perusahaan dapat memanfaatkan penghematan pajak dengan membayar bunga pinjaman untuk meningkatkan nilai perusahaan dengan menggunakan pendanaan utang yang sebaliknya menyebabkan perusahaan menanggung risiko kebangkrutan. Teori ini menjelaskan bahwa kombinasi hutang jangka panjang dan modal pribadi yang disusun dengan memperhitungkan penghematan pajak dapat menciptakan nilai perusahaan yang lebih tinggi. Trade Off Theory berasumsi bahwa apabila perusahaan menggunakan hutang jangka panjang hingga pada tingkat tertentu, perusahaan dapat memperoleh tingkat laba yang lebih optimal karena adanya pengehematan pajak

Menurut Anthony dan Govindarajan dalam Siagian (2011), Agency Theory (Teori Agensi) adalah konsep yang menggambarkan hubungan antara prinsipal dan agen dalam mengelola perusahaan. Konflik kepentingan antara prinsipal dan agen akan menimbulkan kerugian bagi perusahaan. Menurut Jensen dan Mackeling dalam Siagian (2011), biaya yang harus dikeluarkan untuk mengawasi kinerja agen untuk mencegah terjadinya masalah keagenan disebut juga sebagai agency cost (biaya keagenan). Untuk mengurangi besarnya agency cost, prinsipal dapat melakukan pengawasan melalui kebijakan pendanaan dalam penyusunan struktur modal. Penggunaan hutang dalam struktur modal akan menyebabkan agen memiliki tanggung jawab untuk membayar beban bunga secara berkala dan pokok hutang pada akhir periode pinjaman. Kegagalan membayar hutang akan menyebabkan agen terancam kehilangan pekerjaan dan meningkatnya risiko default (kebangkrutan) perusahaan. Untuk mencegah hal tersebut, agen akan mengelola penggunaan arus kas dengan seefisien mungkin dan mencegah pengambilan keputusan investasi yang tidak optimal.

Brigham dan Houston (2011) menjelaskan bahwa Signaling Theory berkaitan dengan tindakan yang diambil perusahaan yang akan dijadikan sebagai petunjuk mengenai prospek perusahaan di masa depan bagi investor. Penggunaan hutang dapat dijadikan sebagai sinyal mengenai prospek perusahaan. Komposisi hutang yang terlalu besar di struktur modal dapat menurunkan kepercayaan investor terhadap saham. Hal ini disebabkan perusahaan akan memiliki tanggungan untuk membayar bunga dan pokok hutang yang kemungkinan akan melebihi kemampuan perusahaan untuk melunasinya.

Munawir (2004) mendefinisikan profitabilitas sebagai ukuran yang menggambarkan kapabilitas perusahaan dalam menghasilkan keuntungan dalam suatu periode tertentu. Jusup (2011) menjelaskan profitabilitas digunakan dengan tujuan untuk mengukur tingkat keberhasilan perusahaan dalam bentuk laba dalam suatu periode tertentu. Baik investor maupun kreditor biasanya menilai kesehatan perusahaan berdasarkan tinggi rendahnya profitabilitas perusahaan tersebut. Kasmir (2015) berpendapat bahwa profitabiltas merupakan 
rasio yang berguna untuk mengevaluasi keberhasilan perusahaan dalam mencetak laba dalam periode tertentu.

Syamsuddin (2012) mendeskripsikan struktur aktiva sebagai penentuan komposisi alokasi dana bagi setiap komponen aktiva, baik aktiva tetap maupun aktiva lancar. Dalam alokasi dana ini, perusahaan menentukan jumlah uang yang diinvestasikan pada aktiva lancar dan aktiva tetap. Riyanto (2001) menjelaskan struktur aktiva sebagai perbandingan atau perimbangan antara aktiva lancar dan aktiva tetap dalam bentuk nominal (absolut) dan bentuk presentase (relatif).

Menurut pendapat Sujianto (2001), ukuran perusahaan adalah gambaran dari besar atau kecilnya suatu perusahaan yang dihitung berdasarkan jumlah penjualan, total aktiva, rata-rata total aktiva, dan rata-rata penjualan aktiva. Riyanto (2001) mendefinisikan ukuran perusahaan sebagai besar atau kecilnya suatu perusahaan berdasarkan nilai perusahaan, nilai modal, dan nilai total aktiva.

Horne dan Wachowicz (2001) mendefinisikan likuiditas sebagai ukuran dari kemampuan perusahaan untuk melunasi hutang jangka pendeknya dengan aktiva lancar yang tersedia untuk membayar hutang-hutang tersebut. Menurut Fahmi (2012), likuiditas dapat didefiniskan sebagai kemampuan perusahaan dalam membayar hutang jangka pendeknya dengan tepat waktu. Riyanto (2001) menjelaskan likuiditas sebagai kemampuan perusahaan untuk melunasi kewajiban keuangannya yang harus segera dibayarkan.

Menurut Swastha dan Handoko (2001), pertumbuhan penjualan adalah alat indikator yang penting dari performa produk barang atau jasa perusahaan dengan mengukur jumlah pendapatan yang diperoleh dari menjual produk tersebut untuk menilai pertumbuhan penjualan. Pertumbuhan penjualan juga menunjukkan tinggi rendahnya permintaan terhadap produk dan daya saing perusahaan di dalam industri. Menurut Tambunan (2008), pertumbuhan penjualan merupakan ukuran yang membandingkan pertumbuhan penjualan suatu perusahaan dari tahun ke tahun.

\section{METODOLOGI PENELITIAN}

Penelitian ini difokuskan pada perusahaan-perusahaan manufaktur yang terdaftar di Bursa Efek Indonesia selama tahun 2014-2018. Data-data keuangan perusahaan dapat diperoleh dari laporan tahunan dan laporan keuangan yang dapat diunduh dari website www.idx.co.id dan website perusahaan tersebut. Jumlah perusahaan yang menjadi sampel penelitian adalah 92 perusahaan dari 178 perusahaan manufaktur. Penelitian ini diuji menggunakan Eviews 9.0 dengan teknik estimasi data panel, yaitu uji chow, uji hausman, uji Langrange-Multiplier, uji common effect, uji fixed effect, dan uji random effect.

Variabel operasional dalam penelitian ini adalah profitabilitas, struktur aktiva, ukuran perusahaan, likuiditas, dan pertumbuhan penjualan sebagai variabel independen, sedangkan struktur modal dipilih sebagai variabel dependen. Profitabilitas diukur dengan menggunakan rasio Return on Asset, struktur aktiva diukur dengan menggunakan Fixed Asset Ratio, ukuran perusahaan diukur dengan menggunakaan LogTA, likuiditas diukur menggunakan Current Ratio, dan pertumbuhan penjualan diukur menggunakan Sales Growth.

\section{HASIL DAN KESIMPULAN}

Setelah dilakukan uji Chow, uji Hausman, dan uji Langrange-Multiplier, alat pengujian menemukan bahwa model yang terbaik untuk digunakan dalam penelitian ini adalah model Random Effect dengan hasil sebagai berikut: 


\begin{tabular}{|c|c|c|c|}
\hline \multicolumn{4}{|c|}{$\begin{array}{l}\quad \text { Tabel 1 } \\
\qquad \begin{array}{l}\text { Model Random Effect } \\
\text { Cross-section random effects test equation: } \\
\text { DependentVariable: } Y\end{array} \text { Method: Panel Least Squares } \\
\text { Date: } 05 / 01 / 20 \text { Time: } 12: 12 \\
\text { Sample:2014 2018 } \\
\text { Periods included:5 } \\
\text { Cross-sections included: } 92 \\
\text { Total panel (balanced) observations: } 460\end{array}$} \\
\hline Variable & Coefficient & Std. Error t-Statistic & Prob. \\
\hline $\begin{array}{l}\mathrm{C} \\
\mathrm{X} 1 \\
\mathrm{X} 2 \\
\mathrm{X} 3 \\
\mathrm{X} 4 \\
\mathrm{X} 5\end{array}$ & $\begin{array}{r}-6.324794 \\
-1.064707 \\
-2.203220 \\
0.911411 \\
-0.258473 \\
0.505196\end{array}$ & $\begin{array}{rr}4.413456 & -1.433071 \\
0.561568 & -1.895954 \\
0.696485 & -3.163342 \\
0.446474 & 2.041354 \\
0.051745 & -4.995092 \\
0.172800 & 2.923578\end{array}$ & $\begin{array}{l}0.1527 \\
0.0588 \\
0.0017 \\
0.0419 \\
0.0000 \\
0.0037\end{array}$ \\
\hline \multicolumn{4}{|c|}{ Effects Specification } \\
\hline \multicolumn{4}{|c|}{ Cross-section fixed (dummy variables) } \\
\hline $\begin{array}{l}\text { R-squared } \\
\text { Adjusted R-squared } \\
\text { S.E. of regression } \\
\text { Sum squared resid } \\
\text { Log likelihood } \\
\text { F-statistic } \\
\text { Prob(F-statistic) }\end{array}$ & $\begin{array}{r}0.789255 \\
0.733521 \\
0.705799 \\
180.8292 \\
-437.9668 \\
14.16108 \\
0.000000\end{array}$ & $\begin{array}{l}\text { Mean dependent var } \\
\text { S.D. dependent var } \\
\text { Akaike info criterion } \\
\text { Schwarz criterion } \\
\text { Hannan-Quinn criter. } \\
\text { Durbin-Watson stat }\end{array}$ & $\begin{array}{l}1.164657 \\
1.367255 \\
2.325943 \\
3.197092 \\
2.668983 \\
2.394313\end{array}$ \\
\hline
\end{tabular}

Berdasarkan hasil dari random effect, hasil analisis regresi berganda adalah sebagai berikut:

Struktur modal $=-6,324794-1,064707$ Profitabilitas $-2,203220$ Struktur Aktiva + 0,911411 Ukuran Perusahaan - 0,258473 Likuiditas + 0,505196 Pertumbuhan Penjualan $+\varepsilon$

\section{KESIMPULAN DAN SARAN}

Berdasarkan hasil pengujian di atas, hasil yang ditemukan adalah profitabilitas, struktur aktiva, dan likuiditas memiliki hubungan yang negatif dengan struktur modal, sedangkan ukuran perusahaan dan pertumbuhan penjualan memiliki hubungan yang positif dengan struktur modal. Dari kelima variabel di atas, hanya profitabilitas yang tidak memiliki pengaruh signifikan terhadap struktur modal.

Manajemen perusahaan manufaktur dapat memperhatikan struktur aktiva, ukuran perusahaan, likuiditas, dan pertumbuhan penjualan karena pengarunya yang terbukti signifikan dalam menyusun struktur modal. Investor juga dapat memperhatikan keempat rasio tersebut untuk menilai kinerja manajemen dalam menyusun kebijakan struktur modal.

Penelitian ini memiliki beberapa keterbatasan, seperti hanya meneliti sektor manufaktur, hanya meneliti 5 variabel independen dan 1 dependen, tidak memperhitungkan adanya variabel mediasi maupun moderasi, hanya meneliti dalam periode 2014-2018 serta tidak memperhitungkan variabel makro. Peneliti selanjutnya diharapkan dapat menggunakan periode penelitian yang lebih panjang, meneliti sektor yang lebih luas, menambahkan variabel indepeneden dan variabel dependen, menambahkan variabel mediasi dan moderasi, serta memperhitungkan variabel makro.

\section{DAFTAR PUSTAKA}

Badan Pusat Statistik. (2019). Produk Domestik Bruto Indonesia Triwulanan 2015-2019. https://www.bps.go.id/publication/2019/10/07/4923ba3ffd04cd25e83dcd97/pdbindonesia-triwulanan-2015-2019.html Diakses pada Senin, 28 Oktober 2019. Pukul : 16.39 WIB.

Brigham, E.F., \& Houston, J.F. (2011). Manajemen Keuangan. Jakarta : Erlangga.

Fahmi, I. (2012). Analisis Laporan Keuangan. Bandung : Alfabeta. 
Gitman, L.J. (2000). Principles of Managerial Finance. Massachusetts : Addison-Wesley Publishing Company

Handoko, T.H. dan Swastha, B. (2001). Prinsip-Prinsip Pemasaran. Jakarta : Gramedia.

Horne, V., James C. \& Wachowich, J.M. (2001). Fundamental of Financial Management. New Jersey : Prentice Hall

Jusup, A.H. (2011). Dasar-dasar Akuntansi. Yogyakarta : Sekolah Tinggi Ilmu Ekonomi YKPN.

Kasmir. (2015). Analisis Laporan Keuangan. Jakarta : PT. Rajagrafindo Persada.

Keown, A.J., Scott, D.F., Martin, J.D., \& Petty, J.W. (2010). Manajemen Keuangan. Jakarta : PT Macanan Jaya Cemerlang.

Munawir. (2004). Analisa Laporan Keuangan. Yogyakarta : Liberty.

Prabansari, Yuke \& Kusuma, Hadri. (2005). Faktor-faktor yang Mempengaruhi Struktur Modal Perusahaan Manufaktur Go Public di Bursa Efek Jakarta. Sinergi Kajian Bisnis dan Manajemen, 1 (2), 1-15.

Riyanto, B. (2001). Dasar-dasar Pembelanjaan Perusahaan. Yogyakarta : BPFE UGM.

Sartono, A. (2010). Manajemen Keuangan Teori dan Aplikasi. Yogyakarta : BPFE.

Siagian, S.P. (2011). Manajemen Sumber Daya Manusia. Jakarta : Bumi Aksara.

Sujianto, Agus Eko. (2001). Analisis Faktor-Faktor yang Mempengaruhi Struktur Keuangan pada Perusahaan Manufaktur yang Go-Public di Bursa Efek Jakarta. Jurnal Ekonomi dan Bisnis, 2 (2).

Syamsuddin, L. (2012). Manajemen Keuangan Perusahaan Konsep Aplikasi dalam : Perencanaan, Pengawasan, dan Pengambilan Keputusan. Bandung : Alfabeta.

Tambunan, R.M. (2008). Standard Operating Procedure (SOP). Jakarta : Maisetas Publishing.

Weston, J. F., \& Copeland, E.T. (1995). Manajemen Keuangan. Jakarta : Gelora Aksara Pratama. 